\title{
On several new series of double oxalates
}

\section{Rees Heece}

To cite this article: M. Rees Heece (1846) On several new series of double oxalates, Philosophical Magazine Series 3, 28:185, 156-157, DOI: 10.1080/14786444608645384

To link to this article: http://dx.doi.org/10.1080/14786444608645384

曲 Published online: 30 Apr 2009.

Submit your article to this journal

Џ Article views: 2

Q View related articles $₫$ 
his results therefore agree with those of Berzelius, Graham and Clark. -Journ. de Pharm. et de Ch., Dec. 1845.

ON SEVERAI NEW SERIES OF DOUBLE OXALATES. BY M. REES HEECE.

These salts were discovered in investigating the action of alkaline and earthy bases on the oxalates of the sesquioxides.

It is well known that the salts of lime produce but a slight precipitation of oxalate of lime in a moderately concentrated solution of the oxalates of the sesquioxides of iron and chromium, \&c., and none in a very dilute solution of oxalate of chromium and potash, a salt discovered by Prof. Gregory, and in which there are 3 equiv. of oxalic acid combined with the alkaline base. A concentrated solution of the same salts gives rise to an abundant precipitate, which has been considered as oxalate of lime, but in which I found a considerable proportion of chromium. These were the facts which led me to pursue this inquiry.

The combination by means of which $I$ have prepared the double salts which are the objects of this memoir, is an oxalate of chromium and ammonia, having the same formula as the salt of Mr. Gregory ; but it is preferable to this on account of its great solubility.

A concentrated solution of this salt, mixed with its volume of chloride of strontium, barium or calcium, yields voluminous precipitates, which, separated from the mother-leys and recrystallized, have the following composition :-

Oxalate of chrome and barytes (A) $3 \mathrm{C}^{2} \mathrm{O}^{3}+\mathrm{Cr}^{3} \mathrm{O}^{3}+3\left(\mathrm{C}^{2} \mathrm{O}^{3} \mathrm{BaO}\right)+12 \mathrm{HO}$. Oxalate of chrome and barytes (B) $3 \mathrm{C}^{2} \mathrm{O}^{3}+\mathrm{Cr}^{2} \mathrm{O}^{3}+2\left(\mathrm{C}^{2} \mathrm{O}^{3} \mathrm{BaO}\right)+18 \mathrm{HO}$. Oxalate of chrome and strontian ... $3 \mathrm{C}^{2} \mathrm{O}^{3}+\mathrm{Cr}^{2} \mathrm{O}^{3}+3\left(\mathrm{C}^{2} \mathrm{O}^{3} \mathrm{SrO}\right)+18 \mathrm{HO}$. Oxalate of chrome and lime ........ $2\left(3 \mathrm{C}^{2} \mathrm{O}^{3}+\mathrm{Cr}^{2} \mathrm{O}^{3}\right)+3\left(\mathrm{C}^{2} \mathrm{O}^{3} \mathrm{CaO}\right)+36 \mathrm{HO}$.

If oxide of iron is substituted for the oxide of chromium, we obtain the corresponding salts with an iron base, and which are represented by the following formulæ:-

Oxalate of iron and barytes ...........3 $3 \mathrm{C}^{2} \mathrm{O}^{3}+\mathrm{Fe}^{2} \mathrm{O}^{3}+3\left(\mathrm{C}^{2} \mathrm{O}^{3} \mathrm{BaO}\right)+7 \mathrm{HO}$. Oxalate of iron and barytes ............. $3 \mathrm{C}^{2} \mathrm{O}^{3}+\mathrm{Fe}^{2} \mathrm{O}^{3}+3\left(\mathrm{C}^{2} \mathrm{O}^{3} \mathrm{BaO}\right)+12 \mathrm{HO}$. Oxalate of iron and strontian ......... $3 \mathrm{C}^{2} \mathrm{O}^{3}+\mathrm{Fe}^{2} \mathrm{O}^{3}+3\left(\mathrm{C}^{2} \mathrm{O}^{3} \mathrm{SrO}\right)+18 \mathrm{HO}$.

The oxalate of iron and of lime does not crystallize.

If alumina is substituted for the oxide of chromium, we obtain similar salts, which are represented by-

Oxalate of alumina and barytes........ $3 \mathrm{C}^{2} \mathrm{O}^{3}+\mathrm{Al}^{2} \mathrm{O}^{3}+3\left(\mathrm{C}^{2} \mathrm{O}^{3} \mathrm{BaO}\right)+10 \mathrm{HO}$. Oxalate of alumina and barytes.......... $3 \mathrm{C}^{2} \mathrm{O}^{3}+\mathrm{Al}^{2} \mathrm{O}^{3}+3\left(\mathrm{C}^{2} \mathrm{O}^{3} \mathrm{BaO}\right)+30 \mathrm{HO}$. Oxalate of alumina and strontian ...... $3 \mathrm{C}^{2} \mathrm{O}^{3}+\mathrm{Al}^{2} \mathrm{O}^{3}+2\left(\mathrm{C}^{2} \mathrm{O}^{3} \mathrm{SrO}\right)+18 \mathrm{HO}$.

The oxalate of alumina and lime cannot be isolated in a state of purity, on account of its insolubility.

These salts crystallize in small silky needles; those of the oxide of chromium are of a dark violet colour, those of iron of a greenishyellow, and those of alumina of a brilliant white. They are soluble in about 30 times their weight of boiling water (excepting the salts of lime and oxide of chromium, of alumina and strontia, which are decomposed by water); they are scarcely soluble in cold. All the alkalies decompose them by precipitating the sesquioxide and earthy 
oxalate. The salts of chromium however behave differently towards ammonia, which does not throw down the oxide of chromium, even when the barytes has been separated by sulphuric acid.

The iron salts are decomposed by the solar rays, with an abundant disengagement of carbonic acid, even when the crystals ure dry.

I shall conclude this summary of my investigations by drawing attention to the importance of these salts in analysis; the more so as it was with this view I undertook them.

I think that I have succeeded in explaining the fact, long since known, of the solubility of the oxalate of lime in solutions of the sesquioxides. Iron, aluminum and chromium are always separated from their ores as sesquioxides; lime and strontia, in the state of oxalates; but we know that lime cannot be separated from the solution of the sesquioxide; this circumstance is owing to the formation of a double salt, of which the oxalate of lime forms a part. It is therefore necessary to precipitate the sesquioxide by ammonia, which leaves the lime free in the solution, and it is therefore difficult to prevent its being thrown down by the carbonic acid of the atmosphere, and thus affecting the weight of the sesquioxide.

It is especially in the case of alumina and oxide of chromium, that the error may be the greatest. This difficulty is easily avoided by the following process :-I will select as an instance a mineral containing iron and lime. It is dissolved in hydrochloric acid; then a suitable quantity of oxalic acid added, which, if the liquor is diluted, will not produce any precipitate; I now add some oxalate of ammonia in excess, which will precipitate the whole of the lime, which is separated by filtration, oxide of iron remaining in solution entirely free from lime; this is precipitated, in the ordinary manner, by ammonia.-Comptes Rendus, Nov, 17, 1845.

\section{REACTION FOR 'IHE DISCOVERY OF SULPHUROUS ACID. BY M. HEINTZ.}

'The substance to be examined, dissolved in water or hydrochloric acid, is to be heated with a solution of protochloride of tin in dilute hydrochloric acid to ebullition. If the liquid contains much sulphurous acid, sulphuret of tin is precipitated; but if the quantity be small, no precipitation occurs; the liquid becomes yellow and exhales the odour of sulphuretted hydrogen. It is then requisite only to add a few drops of solution of sulphate of copper to obtain an immediate precipitate of the brown sulphuret of this metal.

This method of detecting sulphurous acid, it will be observed, is merely a modification of that proposed more than fifty years ago by Pelletier, and since recommended by $M$. Gerard.

It is preferable to the process of MM. Fordos and Gelis, which is based on the formation of sulphuretted hydrogen by the contact of metallic zinc and sulphurous gas, inasmuch as it does not require the use of an apparatus to disengage the gas.-Journ. de Pharm. et de $C h$, Janvier 1846. 